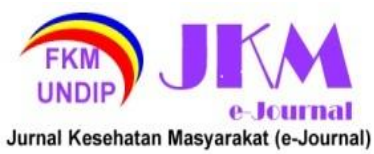

JURNAL KESEHATAN MASYARAKAT (e-Journal)

Volume 10, Nomor 1, Januari 2022

ISSN: 2715-5617 / e-ISSN: 2356-3346

http://ejournal3.undip.ac.id/index.php/jkm

\title{
FAKTOR - FAKTOR YANG BERHUBUNGAN DENGAN STRESS KERJA PADA PETUGAS CALL CENTER NOMOR TUNGGAL PANGGILAN DARURAT (NTPD) JAKARTA SIAGA 112 DI BADAN PENANGGULANGAN BENCANA DAERAH DKI JAKARTA TAHUN 2021
}

\author{
Kevin Antonio $\mathbf{S}^{\text {**, Ade Heryana }}{ }^{2}$, Intan Silviana $\mathrm{M}^{2}$, Anggun Nabila ${ }^{2}$ \\ ${ }^{1}$ Mahasiswa Program Studi Kesehatan Masyarakat, Fakultas Ilmu-Ilmu Kesehatan Universitas Esa Unggul \\ ${ }^{2}$ Dosen Program Studi Kesehatan Masyarakat, Fakultas Ilmu-Ilmu Kesehatan Universitas Esa Unggul \\ *Corespondance author: kevinantonios0205@gmail.com
}

\begin{abstract}
Employees work stress can harm themselves and the company. The purpose of this study was to determine the factors associated with work stress on the call center officer of the Jakarta Emergency Call 112 (NTPD). Research design used cross sectional with quantitative approach. The study was conducted in April 2021 - August 2021. Sample were 40 participant that selected with total sampling method. Data was analyze in univariate and bivariate tests using the chi-square statistical test with $\alpha=0.05$. The results showed call center officers with female sex 21 people (52.5\%), College 33 people (82.5\%), no work stress 23 people (54,7\%), moderate workload 21 people (52.5\%), positive work climate 24 people (60.0\%). Based on bivariate analysis, it was found that there was a relationship between work stress of call center officers and education ( $p$ value $=0.029, P R=2.571$ ). Based on bivariate analysis, it was found that there was a relationship between work stress of call center officers and education ( $p$ value $=0.029, P R=2.571$ ). It is hoped that the company's management will conduct emergency training and communication training on a regular basis to help officers with low education be better prepared to serve the community. In addition, management provides stress management counseling activities and provides sports facilities and vacation activities for staff relaxation.
\end{abstract}

Keywords: work stress, gender, education, workload, work climate, working time

\section{PENDAHULUAN}

Di era globalisasi saat ini kondisi kesehatan pada pekerja merupakan hal yang penting untuk diperhatikan. Dalam melakukan pekerjaan tiap individu di suatu organisasi dapat mengalami stress. Hal ini terjadi akibat kondisi pekerjaan yang dikerjakan oleh individu tersebut tidak mampu diadaptasikan dengan kemampuan fisiologi dan psikologi yang dimiliki individu tersebut. ${ }^{1}$

Stres kerja adalah suatu kondisi dimana individu mengalami gangguan dari segi fisik maupun psikis ketika pekerja menghadapi permasalahan di suatu pekerjaan dan tidak mampu menyelesaikan. Pemicu dari stress kerja bisa dari tuntutan kerja yang berlebihan dan ketidakcukupan pekerja dalam beristirahat yang berdampak khusus pada fisik psikis dan perilaku individu tersebut. Individu yang mengalami stress kerja yang berkepanjangan bisa menimbulkan risiko bagi kesehatan dan keselamatan jika tidak segera dicegah atau diatasi. ${ }^{2}$

Stres kerja sudah menjadi masalah di dunia angka kejadian stres kerja di Inggris terhitung ada 385.000 kasus, di Wales mencapai 11.000 sampai 26.000 kasus. Oleh sebab itu stres kerja menjadi perhatian penting salah satunya pada pekerja sektor pelaksanaan kesehatan. ${ }^{1}$

Stres kerja yang dialami oleh pekerja dapat mempengaruhi performa organisasi dalam mencapai target perusahaan. Selain itu, menurut WHO, organisasi yang tidak sehat tidak akan mendapatkan usaha terbaik yang diberikan para pekerjanya. Hal ini tidak hanya berdampak pada performa organisasi, tetapi juga untuk keberlangsungan organisasi kedepannya.

Berdasarkan hasil survei Regus pada tahun 2012 dilaporkan tingkat stres kerja di Indonesia 73\% dalam hal ini Indonesia mengalami peningkatan sebesar 9\% dari tahun sebelumnya yang hanya berada $64 \%$ di tingkat stres kerja. $^{3}$ Indeks kebahagiaan yang dirilis oleh Badan Pusat Statistik juga mengatakan bahwa Provinsi DKI hanya meraih indeks 71,33 dari 75,68 yang diraih Provinsi Maluku Utara sebagai provinsi paling bahagia di Indonesia.

Data dinas kependudukan menunjukkan bawa DKI Jakarta memiliki penduduk yang sudah mencapai 9,5 juta jiwa. Sekitar 1,33 juta penduduk DKI Jakarta dari 9,5 juta jiwa diperkirakan mengalami gangguan kesehatan mental dengan kategori stress akut akibat kerja mencapai 1-3\% dan stress kerja kategori berat mencapai 7-10\%. ${ }^{4}$ Hasil penelitian Zipjet pada tahun 2017 menyatakan bahwa Jakarta berada pada urutan 132 dari 150 kota paling stres di dunia.

Pada penelitian yang dilakukan Wachid, menyatakan bahwa penelitian yang mereka lakukan di PT. Telekomunikasi Indonesia,Tbk Lampung Tahun 2019 faktor risiko yang mempengaruhi stress kerja adalah beban kerja dan masa kerja. ${ }^{5}$ Selain itu, penelitian yang dilakukan Candra, menyatakan bahwa penelitian yang mereka lakukan di PT.X faktor risiko yang mempengaruhi stress kerja adalah pendidikan dan kebisingan. ${ }^{6}$ 


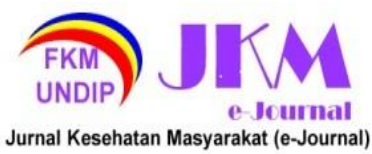

Badan Penanggulangan Bencana Daerah (BPBD) merupakan lembaga penanggulangan bencana yang berkedudukan di bawah dan bertanggung jawab kepada Gubernur. BPBD dipimpin oleh seorang kepala, yang dijabat secara ex officio oleh Sekretaris Daerah (Sekda), yang berkedudukan di bawah dan bertanggung jawab kepada Gubernur. Terbentuknya BPBD Provinsi DKI Jakarta sejak Februari 2011 diharapkan Manajemen Penanggulangan Bencana di DKI Jakarta akan lebih baik karena dikelola sejak sebelum, saat dan setelah bencana (Peraturan Kepala Badan Penanggulangan Bencana Nomor 4 Tentang Pedoman Penyusunan Rencana Penanggulangan Bencana, 2008).

Layanan Nomor Tunggal Panggilan Darurat (NTPD) Jakarta Siaga 112 adalah salah satu bagian yang ada pada Unit Perlaksana Teknis Pusat Data dan Informasi Kebencanaan yang ada di Badan Penanggulangan Bencana Daerah Provinsi DKI Jakarta untuk memberikan pelayanan sebaik mungkin terhadap masyarakat.DKI Jakarta.?

Sesuai dengan Instruksi Gubernur Provinsi Daerah Khusus Ibu Kota Jakarta Nomor 142 Tentang Pengamanan Aset Milik Pemerintah Provinsi Daerah Khusus Ibu Kota Jakarta (2016) NTPD 112 terhubung dengan beberapa Satuan Kerja Pemerintah Daerah (SKPD) terkait seperti Dinas Kesehatan, Dinas Penanggulangan Kebakaran dan Penyelamatan, Dinas Perhubungan, Satuan Polisi Pamong Praja (Satpol PP), serta Polda Metro Jaya. Warga dapat mengandalkan layanan darurat 112 selama 24 jam sehari, 7 hari seminggu dan bisa mengaksesnya melalui semua operator telepon, baik telepon seluler maupun telepon rumah. Panggilan ini bebas biaya dan dapat dilakukan bahkan dalam kondisi ponsel tanpa SIM card, namun masih dalam jangkauan sinyal layanan operator.

Petugas call center NTPD Jakarta Siaga 112 dalam 1 hari kerja dituntut untuk bisa melayani laporan pengaduan masyarakat dengan fast respon. Fast respon yang dimaksud petugas harus menjawab call yang masuk dengan standar waktu $<10$ detik lalu mendengarkan laporan, memberikan solusi sampai menginput laporan di tiket kurang dengan waktu < 10 menit. Dalam kesehariannya petugas mampu melayani pengaduan masyarakat sekitar 500 sampai 1000 call perhari dengan jumlah kasus yang berbeda beda.mulai dari laporan yang bersifat emergency seperti kebakaran, tindakan kriminal, bencana alam, kecelakaan dan sebagainya. Tidak hanya laporan emergency, laporan non emergency seperti segala informasi terbaru yang sedang beredar di berita seringkali ditanyakan oleh masyarakat yang menghubungi dan petugas harus bisa memberikan solusinya.

Petugas harus mempunyai kemampuan saat melayani laporan dengan smailing voice, cepat dalam mengetik, cepat dalam memberikan informasi dan memiliki empati dalam mendengarkan segala keluhan masyarakat. Dengan kondisi petugas yang shifting dan laporan 500 - 1000 call perhari, tipe tipe pelapor pun berbeda, ada yang bernada sopan dan tidak sedikit pula pengaduan yang masuk berisi nada menghina ke petugas call center. Namun petugas tetap harus melayani dengan sabar dan tidak terpancing emosi jika mendapatkan laporan yang berisi ujaran kebencian.

Dengan rutinitas sehari hari laporan yang masuk dengan kondisi yang beragam berdampak pada sisi psikologis petugas. Dampak stress kerja terlihat pada petugas call center Nomor Tunggal Panggilan Darurat Jakarta Siaga 112 diantaranya petugas mengalami penurunan produktifitas kerja dan peningkatan absensi. Dari observasi juga terlihat beberapa petugas mengalami gejala stress dari segi fisik yaitu sering mengeluh sakit kepala dan sulit tidur. Selain itu juga petugas mengalami gejala stress dari segi perilaku yaitu sulit untuk mengontrol emosi dan sering mudah tersinggung. Oleh sebab itu, untuk lebih memastikan peneliti tertarik melakukan studi pendahuluan untuk melihat stress kerja pada petugas call center Nomor Tunggal Panggilan Darurat Jakarta Siaga 112.

Berdasarkan hasil studi pendahuluan yang dilakukan oleh peneliti petugas call center Nomor Tunggal Panggilan Darurat Jakarta Siaga 112 di Badan Penanggulangan Bencana Daerah Kota DKI Jakarta Tahun 2021 terhadap 10 responden dengan menggunakan kuesioner DASS 21 didapatkan 8 responden $(80 \%)$ yang mengalami stress. Dari 10 responden yang mengalami stres terbagi atas; 2 responden $(20 \%)$ mengalami stres berat; 2 responden (20\%) mengalami stress sedang; dan 3 responden $(30 \%)$ mengalami stres ringan; sedangkan 3 responden (30\%) tidak mengalami stres.

Dari hasil responden $80 \%$ yang mengalami stress kerja didapatkan indikasi yang sangat sering dirasakan oleh responden yang mengalami stress adalah sulit untuk mengembangkan inisiatif untuk melakukan suatu pekerjaan $(30 \%)$ dan merasa tidak ada yang dapat diharapkan di masa depan dari pekerjaan (20\%). Dalam hal ini dapat di dilihat bahwa masih terdapat permasalahan stres kerja yang dialami oleh petugas call center Nomor Tunggal Panggilan Darurat (NTPD) Jakarta Siaga 112 di Badan Penanggulangan Bencana Daerah Kota DKI Jakarta Tahun 2021.

Berdasarkan latar belakang tersebut maka perlu diadakan pengkajian lebih lanjut mengenai hal - hal yang berkaitan dengan stres kerja yang dialami petugas call center sehingga peneliti tertarik untuk melakukan penelitian yang berjudul "Faktor-Faktor Yang Berhubungan Dengan Stress Kerja Pada Petugas Call Center Nomor Tunggal Panggilan 


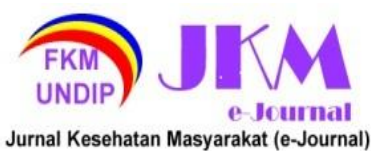

Darurat (NTPD) Jakarta Siaga 112 Di Badan Penanggulangan Bencana Daerah Kota DKI Jakarta Tahun 2021"'

\section{METODE PENELITIAN}

Penelitian ini menggunakan metode kuantitatif dengan menggunakan pendekatan cross sectional untuk memperoleh faktor - faktor yang berhubungan dengan stress kerja pada petugas call center Nomor Tunggal Panggilan Darurat (NTPD) Jakarta Siaga 112 di Badan Penanggulangan Bencana Daerah DKI Jakarta Tahun 2021. Penelitian ini dilaksanakan pada bulan April 2021 sampai Agustus 2021 di Badan Penanggulangan Bencana Daerah DKI Jakarta. Populasi dalam penelitian ini adalah seluruh petugas call center yang ada di Badan Penanggulangan Bencana Daerah DKI Jakarta yang berjumlah 40 responden. Teknik pengambilan sampel dengan menggunakan total sampling dimana seluruh populasi dijadikan sebagai sampel yaitu sebanyak 40 petugas call center. Kriteria eksklusi dalam penelitian ini adalah petugas call center yang tidak bersedia menjadi responden. Pengumpulan data dilakukan menggunakan data primer melalui kuesioner dalam bentuk google form

\author{
Volume 10, Nomor 1, Januari 2022 \\ ISSN: 2715-5617 / e-ISSN: 2356-3346 \\ http://ejournal3.undip.ac.id/index.php/jkm
}

\section{HASIL}

1. Analisis Univariat

Tabel 1. Distribusi frekuensi stress kerja, jenis kelamin, pendidikan, beban kerja, iklim kerja, waktu kerja Petugas Call Center Nomor Tunggal Panggilan Darurat (NTPD) Jakarta Siaga 112 di Badan Penanggulangan Bencana Daerah DKI Jakarta Tahun 2021

\begin{tabular}{lccc} 
& Variabel & Jumlah & Presentase \\
& & $\mathbf{4 0}$ & $\mathbf{1 0 0 \%}$ \\
\hline Dependen & Stress Kerja & 17 & $42,5 \%$ \\
Stress Kerja & Tidak Stress Kerja & $57,5 \%$ \\
Independen & & 23 & \\
Jenis Kelamin & Perempuan & & $52,5 \%$ \\
& Laki-Laki & 21 & $47,5 \%$ \\
Pendidikan & SMA & 19 & $17,5 \%$ \\
& Perguruan Tinggi & 7 & $82,5 \%$ \\
Beban Kerja & Berat & 33 & $37,5 \%$ \\
& Sedang & 15 & $52,5 \%$ \\
Iklim Kerja & Ringan & 21 & $10,0 \%$ \\
& Negatif & 4 & $40,0 \%$ \\
Waktu Kerja & Positif & 16 & $60,0 \%$ \\
& Pagi & 24 & $25,0 \%$ \\
& Siang & 10 & $25,0 \%$ \\
& Sore & 10 & $25,0 \%$ \\
& Malam & 10 & $25,0 \%$ \\
\hline
\end{tabular}

Berdasarkan tabel 1 hasil penelitian terhadap 40 responden. Diketahui bahwa sebanyak 40 responden petugas call center yang tidak stress kerja yaitu 23 orang $(57,5 \%)$, jenis kelamin petugas call center di BPBD DKI Jakarta Tahun 2021 yaitu 21 responden $(52,5 \%)$ perempuan, beban kerja sedang sebanyak 21 responden yang disebarkan melalui aplikasi WhattApp untuk melihat faktor - faktor yang berhubungan dengan stress kerja petugas call center yang meliputi jenis kelamin, pendidikan, beban kerja, iklim kerja dan waktu kerja. Iklim kerja dibagi menjadi dua yaitu iklim negatif dan positif dengan nilai cut of point 41,00 (median) berdasarkan uji Kolmogorov. Hasil uji validitas menggunakan uji product moment dan uji reliabilitas menggunakan Cronbrach Alpha menunjukkan seluruh variable yang diuji valid dan reliabel. Pengolahan data dilakukan dengan menggunakan software computer yaitu aplikasi statistik. Analisis univariat bertujuan untuk memperoleh gambaran stress kerja pada petugas call center, jenis kelamin, pendidikan, beban kerja, iklim kerja dan waktu kerja. Analisis bivariat dilakukan menggunakan table kontigensi $2 \times 2$, uji chi square untuk mengetahui hubungan antara variabel independen (jenis kelamin, pendidikan, beban kerja, iklim kerja dan waktu kerja) dengan variabel dependen (stress kerja) berdasarkan nilai p-value, dan nilai prevalensi ratio untuk mengetahui tingkat resiko antara variable independent dengan dependen. 


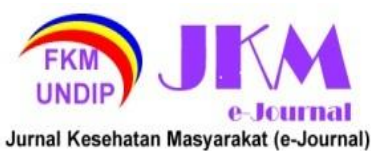

JURNAL KESEHATAN MASYARAKAT (e-Journal)

Volume 10, Nomor 1, Januari 2022

ISSN: 2715-5617 / e-ISSN: 2356-3346

http://ejournal3.undip.ac.id/index.php/jkm

Tabel 2. Uji Statistik faktor - faktor yang berhubungan dengan stress kerja Petugas Call Center Nomor Tunggal Panggilan Darurat (NTPD) Jakarta Siaga 112 di Badan Penanggulangan Bencana Daerah DKI Jakarta Tahun 2021

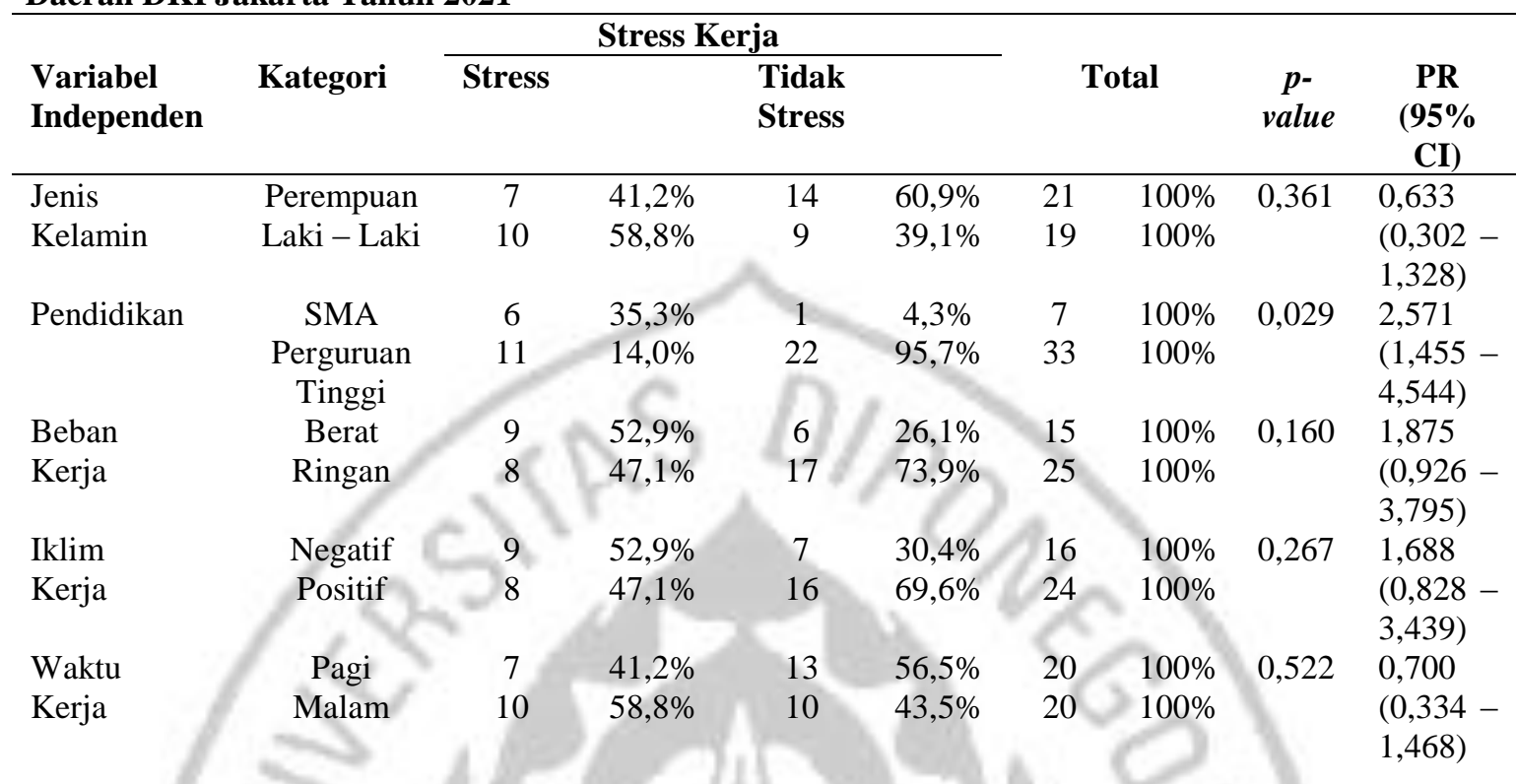

Berdasarkan tabel 2 hasil bivariat pada uji chi square menunjukan bahwa ada hubungan antara stress kerja petugas call center dengan pendidikan ( $\mathrm{p}$ value $=0,029, \mathrm{PR}=2,571$ ). Tidak ada hubungan antara stress kerja tenaga call center dengan jenis kelamin ( $\mathrm{p}$ value $=0,361$, $\mathrm{PR}=0,633$ ), beban kerja ( $\mathrm{p}$ value $=0,160, \mathrm{PR}$ $=1,875)$, iklim kerja $(\mathrm{p}$ value $=0,267, \mathrm{PR}=$ 1,688 ) dan waktu kerja ( $\mathrm{p}$ value $=0,522, \mathrm{PR}=$ $0,700)$.

\section{PEMBAHASAN}

Gambaran Stress Kerja Petugas Call Center Nomor Tunggal Panggilan Darurat (NTPD) Jakarta Siaga 112 di Badan Penanggulangan Bencana Daerah DKI Jakarta Tahun 2021

Berdasarkan hasil penelitian stress kerja sebagian besar petugas call center didapatkan data bahwa responden yang mengalami stress kerja kategori sering pada pernyataan nomor 1 yaitu mengeluh gangguan sulit beristirahat dan pernyataan nomor 2 yaitu mengeluh mulut kering. Menurut Arden Stress Kerja tentu bisa kita lihat secara nyata, ciri-ciri stress kerja yang bisa ditunjukan bisa dari fisik (kepala nyeri, tidak nafsu makan, sulit tidur, mukosa kering, nafas cepat, dan lain lain), psikologis (mudah putus asa, tidak sabaran, mudah cemas dan lain lain) dan watak atau perilaku (sering gelisah, sering absen kerja, pekerjaan sering tidak selesai, dan lain lain). ${ }^{8}$

Jenis pekerjaan sebagai call center dengan jam kerja yang berubah - ubah setiap minggunya terutama petugas laki - laki yang selalu ditempatkan pada waktu kerja malam hari merubah pola tidur petugas laki laki terutama yang sudah menikah dimana ketika pulang kerja pagi hari tidak bisa langsung beristirahat karena beberapa ada yang harus mengantar anak sekolah dan kegiatan lainnya. Selain itu, petugas dituntut berbicara selama 8 jam kerja dengan intonasi yang sama dengan kondisi jam istirahat dibatasi hanya 1 jam sehingga bisa menimbulkan gejala fisik mulut kering pada petugas.

Berdasarkan penelusuran literatur diketahui bahwa jika seseorang tidak mendapatkan jumlah tidur yang cukup maka kerja fungsi otak dalam hal menyimpan atau mengambil informasi dan kemampuan untuk mentoleransi situasi stress dan berfungsi pada tingkat yang lebih tinggi dapat terganggu dan tidak optimal sehingga dapat memicu stress. ${ }^{9}$ Selain itu kondisi mulut kering sering dirasakan pada penderita stress kerja akibat adanya gangguan emosional yang mengakibatkan sekresi saliva menjadi menurun. ${ }^{10}$

Hubungan antara Jenis Kelamin dengan Stress Kerja Petugas Call Center Nomor Tunggal Panggilan Darurat (NTPD) Jakarta Siaga 112

Berdasarkan hasil penelitian diketahui bahwa sebagian petugas call center berjenis kelamin perempuan. Berdasarkan hasil analisis chi square diketahui tidak ada hubungan antara jenis kelamin dengan stress kerja pada petugas call center. Hasil penelitian variabel jenis kelamin mendapatkan nilai PR 0,633 $\quad(P R<1)$ artinya variabel jenis kelamin merupakan faktor proteksi atau pencegah terjadinya stress kerja. Jenis pekerjaan sebagai call 


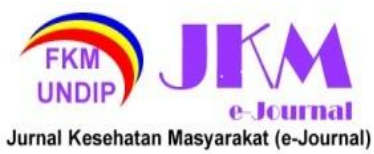

center di Badan Penanggulangan Bencana Daerah tidak ada perbedaan antara laki-laki dan perempuan. Keduanya memiliki tanggung jawab yang sama.

Jenis Kelamin memang bukan sebuah hal yang dapat menentukan tingkat stress yang dialami oleh seseorang. Hal ini sejalan dengan penelitian terdahulu uang dilakukan oleh Abdurrahman tidak terdapat hubungan jenis kelamin terhadap stress kerja pada agent contact center PLN 123 di PT PLN (PERSERO) Perempuan dan laki laki mempunyai peran dan tanggung jawab yang sama dalam pekerjaan. Tidak ada intensitas pekerjaan yang lebih tinggi diantara perempuan dan laki laki. ${ }^{10}$ Dalam pekerjaan baik perempuan dan laki laki sama sama melayani masyarakat melalui perangkat call center yang sudah disediakan dengan jumlah 8 jam kerja yang sama sehingga keduanya memiliki kemampuan menghadapi stress yang sama. Maka jenis kelamin tidak ada hubungan dengan stress kerja.

Hubungan Pendidikan dengan Stress Kerja Petugas Call Center Nomor Tunggal Panggilan Darurat (NTPD) Jakarta Siaga 112

Berdasarkan hasil penelitian diketahui bahwa sebagian besar petugas call center mempunyai pendidikan perguruan tinggi. Berdasarkan hasil chi square diketahui ada hubungan antara pendidikan dengan stress kerja pada petugas call center. Kelompok SMA cenderung memiliki 2,5 kali memiliki risiko terhadap stress kerja dibanding kelompok perguruan tinggi. Penelitian ini sejalan dengan penelitian yang dilakukan oleh Candradutya menyatakan bahwa pendidikan berpengaruh terhadap stress kerja ( $p$ value $<0,001){ }^{6}$

Hasil analisis menyatakan bahwa sebagian besar petugas call center memiliki pendidikan perguruan tinggi. Menurut pengamatan peneliti, penerimaan sumber daya manusia di Badan Penanggulangan Bencana Daerah berlatar belakang pendidikan kesehatan dan manajemen. Adapun petugas yang di berlatar belakang pendidikan SMA hanya 7 orang pada umumnya petugas yang sudah bekerja lama dan berusia diatas 35 tahun. Petugas kelompok SMA cenderung mengalami stress kerja akibat belum memiliki kematangan berfikir dan bersikap sehingga lemah dalam beradaptasi dengan perubahan terutama teknologi yang digunakan, pemikiran yang lebih baik dan bijaksana dalam menyikapi suatu hal di lingkungan kerja yang dapat mengganggu psikologis.

Semakin rendah tingkat pendidikan seseorang cenderung semakin mudah mengalami stress kerja. ${ }^{12}$ Pendidikan memiliki peran untuk mencegah timbulnya stress kerja. Pendidikan yang dimiliki individu akan menimbulkan ketahanan dan kecakapan dalam menghadapi pekerjaan. Seringkali akibat pendidikan yang rendah pekerja tidak mampu mengatasi situasi yang dialami karena tidak dibekali pendidikan yang cukup sehingga meningkatkan tingkat stress kerja. ${ }^{13}$

Berdasarkan masalah diatas maka perlu adanya peran instansi dalam memperhatikan kondisi psikis petugas terutama pada petugas berlatar belakang pendidikan SMA. Instansi mungkin bisa memberikan konseling dan pelatihan yang lebih kepada kelompok SMA untuk bisa menanggulangi stress kerja.

Hubungan antara Beban Kerja dengan Stress Kerja Petugas Call Center Nomor Tunggal Panggilan Darurat (NTPD) Jakarta Siaga 112

Berdasarkan hasil penelitian diketahui bahwa sebagian besar petugas call center memiliki beban kerja berat. Berdasarkan hasil chi square diketahui tidak ada hubungan antara beban kerja dengan stress kerja pada petugas call center. Hasil penelitian variabel beban kerja mendapatkan nilai PR 1,8 $(\mathrm{PR}=1)$ artinya variabel beban kerja bukan faktor risiko terjadinya stress kerja. Hasil yang lebih mendominasi dari segi indikator mental demand dan own performance dimana petugas dituntut aktivitas kerja untuk memiliki kemampuan memahami melalui panca indera seperti melihat, mengingat dan mendengar dimana indikator ini sangat penting dimiliki oleh petugas call center

Meskipun beban kerja yang dialami petugas call center tinggi ini tidak langsung mempengaruhi tingkat stress kerja petugas. Hal ini bisa terjadi karena petugas selain sudah bisa beradaptasi dengan pekerjaan, petugas juga diberikan pelatihan call center dan selalu melakukan briefing sebelum melakukan tugas sehingga sudah memiliki persiapan yang cukup matang dan arahan dari pimpinan yang jelas sebelum melakukan pekerjaan

Hubungan beban kerja dengan stress kerja tidak signifikan dirasakan apabila petugas memiliki kapasitas koping yang baik dalam menanggapi tingkat beban yang terlalu besar sehingga tidak memicu timbulnya stress kerja. ${ }^{13}$ Sejalan dengan penelitian terdahulu yang dilakukan oleh Ramadhania tidak ditemukan hubungan signifikan antara beban kerja dengan stress kerja pada petugas call center di PT. XYZ Tahun 2015. ${ }^{14}$ Hal ini bisa terjadi karena manajemen perusahaan memperhatikan kesiapan petugas dengan memberikan berbagai pilihan pelatihan komunikasi dan manajemen waktu secara berkala dengan cara setiap petugas mengajukan pelatihan yang diinginkan untuk meningkatkan kemampuan dalam pekerjaan sehingga koping dalam menghadapi stress kerja bisa terbentuk. 


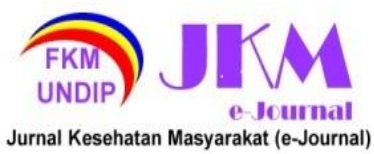

Hubungan antara Iklim Kerja dengan Stress Kerja Petugas Call Center Nomor Tunggal Panggilan Darurat (NTPD) Jakarta Siaga 112

Berdasarkan hasil penelitian diketahui bahwa petugas call center mempunyai iklim kerja positif. Berdasarkan hasil chi square diketahui tidak ada hubungan antara iklim kerja dengan stress kerja pada petugas call center. Hasil penelitian variabel iklim kerja mendapatkan nilai PR 1,6 (PR = 1) artinya variabel iklim kerja bukan faktor risiko terjadinya stress kerja. Artinya semakin positif atau negatif iklim kerja tidak ada kaitannya dengan stress kerja di Badan Penanggulangan Bencana Daerah DKI Jakarta.

Dalam penelitian ini iklim kerja tidak berpengaruh kepada stress kerja karena sesuai dengan hasil kuesioner yang dirasakan petugas didominasi oleh pernyataan bahwa petugas sudah diberikan aturan dan prosedur yang jelas dari perusahaan dan adanya hubungan yang baik antar rekan kerja. Sejalan dengan teori bahwa Iklim kerja yang mendukung pekerja dapat menimbulkan kepuasan dalam bekerja sehingga menyebabkan terjadinya stress kerja. ${ }^{13}$ Sejalan dengan penelitian sebelumnya yang dilakukan oleh Abdillah tidak terdapat hubungan iklim organisasi kerja terhadap stress kerja pada karyawan. ${ }^{15}$ Hal tersebut bisa terjadi karena iklim kerja di lingkungan tersebut sangat terbuka dimana karyawan bisa memberikan masukan dan pendapat ke manajemen terkait perbaikan pekerjaan selain itu juga manajemen memberikan penghargaan bagi karyawan yang berpretasi sehingga iklim kerja bukan faktor yang mempengaruhi stress kerja pada karyawan tersebut.

Hubungan antara Waktu Kerja dengan Stress Kerja Petugas Call Center Nomor Tunggal Panggilan Darurat (NTPD) Jakarta Siaga 112

Berdasarkan hasil penelitian diketahui bahwa petugas call center mempunyai jumlah petugas yang sama dalam setiap waktu kerja.. Berdasarkan hasil chi square diketahui tidak ada hubungan antara waktu kerja dengan stress kerja pada petugas call center. Hasil penelitian variabel waktu kerja mendapatkan nilai PR 0,700 (PR < 1) artinya variabel waktu kerja merupakan faktor proteksi atau pencegah terjadinya stress kerja.

Pada penelitian ini tidak terdapat hubungan antara waktu kerja dengan stress kerja dapat terjadi karena pekerja sudah beradaptasi dengan baik dengan jadwal jam kerja mereka yang harus berbeda. Setiap petugas juga tidak merasakan jam kerja yang berbeda seperti laki laki yang hanya mendapatkan waktu kerja sore dan malam sedangkan perempuan hanya pada jam kerja pagi dan siang sehingga tubuh sudah bisa beradaptasi dengan baik. Sejalan dengan penelitian terdahulu yang dilakukan oleh Abdurrahman tidak terdapat hubungan waktu kerja terhadap stress kerja pada agent contact center PLN 123 di PT PLN (PERSERO). ${ }^{10}$ Pengaruh pekerjaan terhadap pekerja yang berbeda waktu kerja bisa saja tidak berbeda sehingga stress yang dialami para pekerja tidak dipengaruhi oleh faktor waktu kerja tetapi faktor pekerjaan lainnya. Dengan demikian, tidak terdapat hubungan yang signifikan antara tingkat stress kerja pada pekerja dengan waktu kerja.

\section{KESIMPULAN}

Berdasarkan hasil penelitian menunjukan petugas call center dengan jenis kelamin perempuan 21 orang $(52,5 \%)$, pendidikan perguruan tinggi 33 orang $(82,5 \%)$, tidak stress kerja 23 orang $(54,7 \%)$, beban kerja sedang 21 orang $(52,5 \%)$, iklim kerja positif 24 orang $(60,0 \%)$, waktu kerja terbagi sama rata 10 orang $(25,0 \%)$. Berdasarkan analisa bivariat diperoleh hasil bahwa ada hubungan antara stress kerja dengan pendidikan. Selain itu variabel yang tidak berhubungan dengan stress kerja antara lain jenis kelamin, beban kerja, iklim kerja dan waktu kerja.

\section{SARAN}

Diharapkan manajemen perusahaan membuat kegiatan pelatihan kegawatdaruratan dan pelatihan komunikasi secara berkala untuk membantu petugas yang berpendidikan rendah bisa lebih siap dalam melayani masyarakat. Selain itu manajemen menyediakan kegiatan konseling manajemen stress serta menyediakan fasilitas olahraga dan kegitan liburan untuk relaksasi petugas.

\section{DAFTAR PUSTAKA}

1. Nuraini. Gambaran Kejadian Stres Kerja dengan Menggunakan NIOSH Generic Job Stress Questionaire pada Petugas Kesehatan Ruang Rawat Inap di RS Budi Kemuliaan Tahun 2019. 2019; 1-9.

2. International Labour Office. Psychosocial risks, stress and violence. Psychosocial Risks, Stress and Violence in the World of Work. 2016; 8(12), 1-127.

3. Habibi. Analisis Faktor Risiko Stres Kerja Pada Pekerja Di Unit Produksipt. Borneo Melintang Buana Export. Journal of Nursing and Public Health, 2018; 6(2).

4. Kementrian Kesehatan R.I. Riset Kesehatan Dasar (Riskesdas) 2013. 2013

5. Wachid, A., Budiati, E., \& Rahmadani, F. Faktor Faktor Yang Berhubungan Dengan Stres Kerja Customer Service Di PTTelekomunikasiIndonesia,Tbk Lampung Tahun 2019. Jurnal Ilmu Kesehatan Indonesia (JIKMI), 2020; 1(1).

6. Candraditya, R., \& Dwiyanti, E. Hubungan 


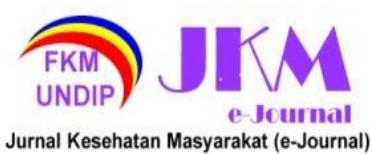

Tingkat Pendidikan, Masa Kerja Dan Tingkat Kebisingan Dengan Stress Kerja Di PT. X. Jurnal Penelitian Kesehatan, 2017; 15(1).

7. Peraturan Gubernur Provinsi Daerah Khusus Ibu Kota Jakarta Nomor 296 Tahun 2016 Tentang Pembentukan, Organisasi dan Tata Kerja Pusat Data dan Informasi Kebencanaan, (2016).

8. Arden. Bekerja Tanpa Stress. PT. Bhuana Ilmu Populer. 2006.

9. Driver. The Youthdale Series 1 insomnia in adults and children. 2012.

10. Hasibuan. (2012). Manajemen SDM (Edisi Revi). Bumi Aksara.

11. Abdurrahman, M., \& Sulaksmono, M. Hubungan Karakteristik Individu Dan Shift Kerja, Dengan Stress Kerja (Studi Pada Agent Contact Center Pln 123 Pt Pln(Persero) Distribusi Jawa Timur Site Surabaya Tahun 2013). Keselamatan Dan Kesehatan Kerja, 2013; 2, 137-144.

12. Kartono. Psikologi Sosial untuk Manajemen Perusahaan dan Industri. Grafindo Persada; 1994.

13. Munandar, A. S. Psikologi Industri dan Organisasi. Universitas Indonesia; 2008.

14. Ramadhania, N., \& Parwati, N. Pengukuran Beban Kerja Psikologis Karyawan Call Center Menggunakan Metode Nasa-Tlx (Task Load Index) Pada PT. XYZ. 2015.

15. Abdillah, M. R., Anita, R., \& Anugerah, R. Dampak Iklim Organisasi Terhadap Stress Kerja Adan Kinerja Karyawan. Jurnal Manajemen, $X X, 2016$; 121-141.

\author{
Volume 10, Nomor 1, Januari 2022 \\ ISSN: 2715-5617 / e-ISSN: 2356-3346
}

http://ejournal3.undip.ac.id/index.php/jkm

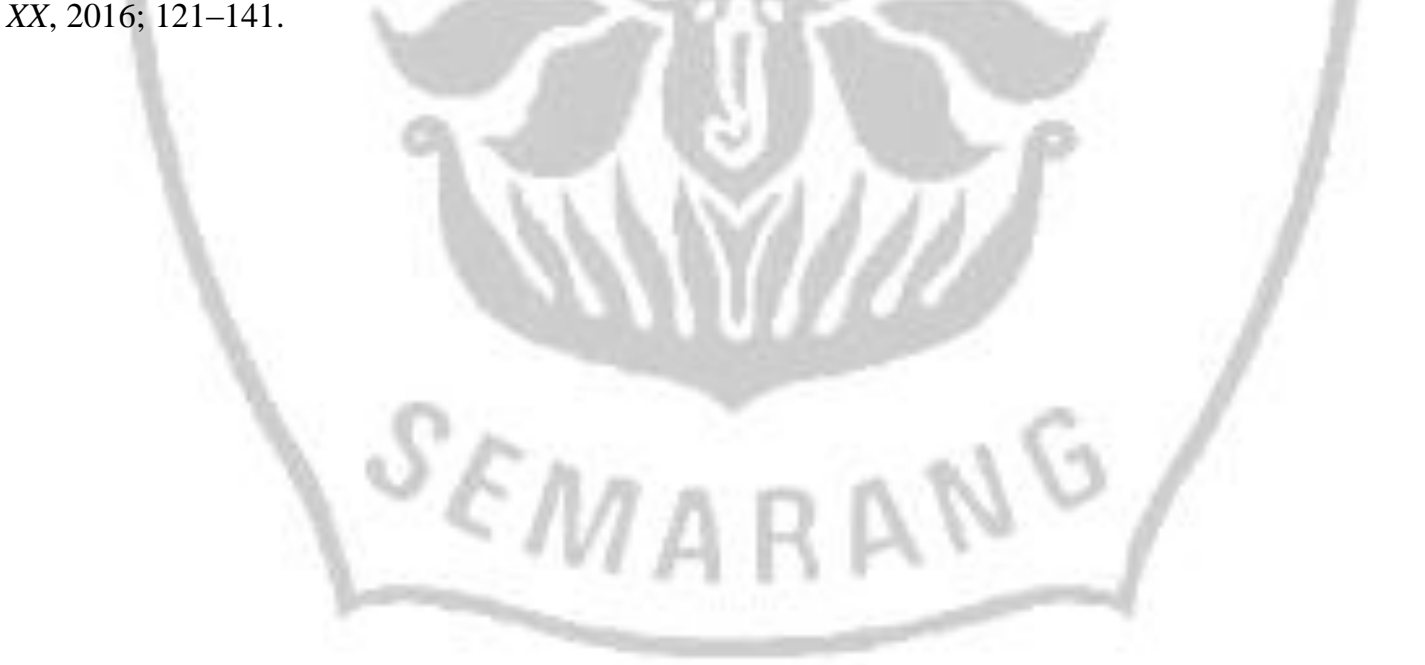

